\title{
KEKUATAN PUTUSAN MAHKAMAH KONSTITUSI DALAM HAL PEMBERHENTIAN PRESIDEN DAN/ATAU WAKIL PRESIDEN
}

\author{
Fauzan Saputra, Muksalmina \\ Fakultas Hukum, STIH AL Banna, Lhokseumawe, Aceh \\ Email: fauzanputra87@gmail.com
}

Diterima : 11 Nop 2020| Direvisi : 30 Nop 2020| Disetujui : 8 Des 2020| Diterbitkan : 14 Des 2020

\begin{abstract}
The dismissal of the President and/or Vice President is governed by the constitution as a legal basis after the amendment. The purpose of this study is to analyze and find the strength of the court's decision in the event of the dismissal of the President and/or Vice President. This research is normative legal research that is a qualitative approach conducted by first examining written legislation established by state agencies or authorized and binding officials in general. The specifications of this study are analytically prescriptive. The data collection techniques used in this study are library research and the analysis used is normative qualitative analysis. The results of this study show that the power of the court's decision in the event of the dismissal of the President and/or Vice President is legally binding because there is no rule of law governing that the court's decision can be reviewed, even if the decisive dismissal of the President and/or Vice President is mpr. Thus, it reflects that Indonesia fully functions the legal state stipulated in Article 1 paragraph (3) of the 1945 Constitution.
\end{abstract}

Keywords: DPR, Constitutional Court, MPR, President and Vice President

\begin{abstract}
ABSTRAK
Pemberhentian Presiden dan/atau Wakil Presiden diatur dalam konstitusi sebagai dasar hukum setelah amandemen. Tujuan penelitian ini adalah untuk menganalisis dan menemukan kekuatan putusan MK dalam hal pemberhentian Presiden dan/atau Wakil Presiden. Penelitian ini merupakan penelitian hukum normatif yaitu pendekatan kualitatif yang dilakukan dengan cara meneliti terlebih dahulu peraturan perundang-undangan tertulis yang dibentuk oleh lembaga negara atau pejabat yang berwenang dan mengikat secara umum. Spesifikasi penelitian ini adalah preskriptif analitis. Teknik pengumpulan data yang digunakan dalam penelitian ini adalah penelitian kepustakaan (library research) dan analisis yang digunakan adalah analisis kualitatif normatif. Hasil penelitian ini menunjukkan bahwa kekuatan putusan MK dalam hal pemberhentian Presiden dan/atau Wakil Presiden mengikat secara hukum disebabkan tidak ada aturan hukum yang mengatur bahwa putusan MK bisa di review, walaupun yang menentukan pemberhentian Presiden dan atau Wakil Presiden adalah MPR. Dengan demikian, mencerminkan bahwa Indonesia sepenuhnya fungsi negara hukum yang diatur dalam Pasal 1 ayat (3) UUD 1945.
\end{abstract}

Kata Kunci: DPR, Mahkamah Konstitusi, MPR, Presiden dan Wakil Presiden 


\section{PENDAHULUAN}

Undang-Undang Dasar (UUD) Tahun 1945 negara Indonesia dalam sistem kepemerintahan lebih cenderung secara formal menganut sistem presidensil bukan parlementer. Salah satu ciri sistem pemerintahan presidensil adalah masa jabatan presiden telah ditentukan dalam konstitusi. ${ }^{1}$ Presiden merupakan pemegang kekuasaan eksekutif yang dikontrol oleh lembaga legislatif dalam menjalankan sistem pemerintahan presidensial. Sebenarnya banyak cara mengontrol jalannya kekuasaan pemerintahan negara, antara lain dengan mekanisme pembatasan jabatan, pengawasan secara ketat oleh lembaga legislatif, dan pemberhentian dari jabatan. ${ }^{2}$

Sehubungan dengan pemberhentian Presiden di Indonesia 75 (tujuh puluh lima) setelah Indonesia merdeka, telah terjadi 2 kali pemberhentian terhadap presiden di Indonesia yaitu: (1) pemberhentian Presiden Soekarno tahun 1967 dan (2) pemberhentian Presiden Abdurrahman Wahid tahun 2001. Hingga sekarang kedua kasus tersebut masih diperdebatkan dengan legalitas atau konstitusionalitas alasanalasan atau proses pemberhentiannya. ${ }^{3}$

Secara konstitusional ketentuan mengenai pemberhentian Presiden diatur dalam UUD 1945 setelah amandemen sebagai sumber hukum di Indonesia. Proses pemberhentian Presiden dan/atau Wakil Presiden wajib berdasarkan konstitusi sebagai manifestasi terhadap negara yang berkedaulatan rakyat yang dijalankan berdasar UUD 1945 dalam Pasal 7 A "Presiden dapat diberhentikan dalam masa jabatannya oleh Majelis Permusyawaratan Rakyat atas usulan dari Dewan Perwakilan Rakyat". Dalam perspektif Pasal 7 B UUD 1945 proses pemberhentian Presiden harus diusulkan oleh Dewan Perwakilan Rakyat (DPR) Kepada Majelis Permusyawaratan Rakyat (MPR). Namun, sebelum pengajuan kepada MPR tentang pemberhentian Presiden dan/atau wakilnya, terlebih dahulu DPR sebagai pihak yang mempunyai kedudukan hukum (legal Standing) harus diajukan tersebut kepada Mahkamah Konstitusi (MK) sebelum upaya di atas dilakukan. DPR harus terlebih dahulu menggunakan hak angket sebagai upaya penyelidikan terhadap kebijakan Presiden yang diduga melanggar aturan hukum dan menggunakan hak menyatakan pendapat sebagai pintu masuk DPR untuk membawa Presiden dan/atau Wakil Presiden kepada MK.

Dengan demikian, praktik ketatanegaraan di Indonesia masih condong menegakkan hukum secara prosedural. Upaya penerapan hukum dan keadilan yang seyogyanya diajukan kepada MK mengenai dugaan DPR atas pelanggaran konstitusi yang dilakukan oleh Presiden dan/atau Wakil Presiden masih terkendala pada proses politik di DPR dengan mekanisme pemungutan suara.

Implikasinya terdapat konflik norma (conflict of norm) antara ketentuan Pasal 1 ayat (3) UUD 1945 yang secara konstitusi menyatakan Indonesia adalah negara hukum dengan ketentuan Pasal 7B ayat (5) UUD 1945 yang menyatakan bahwa "Apabila MK memutuskan bahwa Presiden dan/atau Wakil Presiden terbukti melakukan pelanggaran hukum berupa pengkhianatan terhadap negara, korupsi, penyuapan, tindak pidana berat lainnya, atau perbuatan tercela dan/atau terbukti bahwa Presiden dan/atau Wakil Presiden tidak lagi memenuhi syarat sebagai Presiden dan/atau Wakil Presiden, DPR menyelenggarakan sidang paripurna untuk meneruskan usul pemberhentian Presiden dan/atau Wakil Presiden kepada MPR". Dari bunyi Pasal

\footnotetext{
1 Arend Lijphart, Sistem Pemerintahan Parlementer dan Presidensial,(Jakarta: PT.Raja Grafindo Persada, 1994), hlm. 5.

${ }^{2}$ Hamdan Zoelva, Pemakzulan Presiden di Indonesia, (Jakarta: Sinar Grafika, 2011), hlm. 2.

${ }^{3}$ Ibid.. hlm. 3 .
} 
7B ayat (5) tersebut dimana proses untuk penegakan hukum masih harus berdasarkan kesepakatan politik di DPR terlebih dahulu. ${ }^{4}$

Permohonan DPR atas pelanggaran Presiden dan/atau Wakil Presiden telah berhasil diajukan kepada MK dan MK memutuskan bahwa Presiden dan/atau Wakil Presiden bertentangan dengan konstitusi (unconstitutional), yaitu melanggar Pasal 7A UUD 1945. Namun, dalam pengambilan keputusan untuk memberhentikan Presiden dan/atau Wakil Presiden harus dihadiri oleh sekurang-kurangnya 3/4 dari jumlah anggota MPR dan disetujui oleh sekurang-kurangnya 2/3 dari jumlah anggota MPR yang hadir. Implikasinya, apakah MPR sebagai lembaga politik mampu menjunjung tinggi supremasi hukum sebagaimana diatur dalam Pasal 1 ayat (3) UUD 1945 yang menyatakan bahwa Negara Indonesia adalah Negara hukum, sehingga di dalam melaksanakan keputusan MK tersebut harus disesuaikan dengan perspektif UUD 1945, yang menyatakan bahwa Indonesia adalah negara hukum. ${ }^{5}$

Walaupun demikian mekanisme pemberhentian sebagaimana dijelaskan di atas, Indonesia cenderung tidak menunjukkan karakternya sebagai negara hukum secara sempurna, yaitu tidak terdapat penguatan terhadap supremasi hukum, seperti keputusan hukum MK yang bersifat final dan mengikat (finally binding) dilaksanakan oleh kesepakatan politik di MPR.

Dalam hal ini menarik dilakukan penelitian dengan mengkaji dan menganalisis eksistensi dan konsistensi konstitusi, yaitu antara konsep negara hukum dengan pasalpasal pemberhentian sebagaimana diatur dalam Pasal 7B UUD 1945, serta bagaimana kekuatan keputusan MK yang diajukan oleh DPR yang diduga telah melakukan pelanggaran hukum berupa pengkhianatan terhadap negara, korupsi, penyuapan dan tindak pidana berat lainnya atau melakukan perbuatan tercela dan/atau tidak lagi memenuhi syarat sebagai presiden. Hal tersebut menjadi penting untuk dikaji disebabkan tidak ada satupun aturan baik dalam UUD atau peraturan perundangundangan yang mengatur tentang kewajiban MPR untuk menjalankan secara efektiv putusan MK tersebut. Hal tersebut semakin mengkhawatirkan apabila dukungan politik di MPR kepada presiden semakin banyak. Dalam hal ini banyak kalangan yang menilai bahwa fungsi MK menjadi lemah, sehingga banyak pertanyaan yang muncul jika MK sudah memutuskan bahwa Presiden telah terbukti bersalah, kenapa MPR masih diberikan peluang untuk menganulir putusan MK. Berdasarkan uraian diatas dapat dirumuskan beberapa pokok permasalahan yaitu Bagaimana kekuatan putusan MK terhadap pendapat DPR mengenai dugaan pelanggaran oleh Presiden dan Wakil Presiden menurut UUD 1945?.

\section{METODE PENELITIAN}

Dalam penelitian ini, digunakan metode analisis kualitatif normatif yaitu analisis bahan hukum yang bertitik tolak pada peraturan-peraturan yang berlaku sebagai norma hukum positif dan usaha-usaha untuk menemukan asas-asas dan informasi baru terkait permasalahan yang diteliti. Penelitian ini merupakan penelitian yang baru yang belum pernah diteliti oleh peneliti sebelumnya tentang kekutan kekuatan putusan MK dalam hal pemberhentian presiden dan atau Wakil Presiden. Penelitian ini merupakan penelitian hukum normatif yaitu pendekatan yang dilakukan

\footnotetext{
${ }^{4}$ Jimly Asshiddiqie, Hukum Tata Negara dan Pilar-Pilar Demokrasi, (Jakarta: Konstitusi Press, 2005), hlm. 24.

${ }^{5}$ Ibid, hlm 25.
} 
dengan cara meneliti terlebih dahulu peraturan perundang-undangan tertulis yang dibentuk oleh lembaga negara atau pejabat yang berwenang dan mengikat secara umum. ${ }^{6}$ Spesifikasi penelitian ini adalah preskriptif analitis. Preskriptif dalam arti bahwa penelitian ini mempelajari tujuan hukum, nilai-nilai keadilan, validitas aturan hukum, konsep-konsep hukum dan norma-norma hukum, tentang kekuatan putusan MK dalam proses pemberhentian Presiden menurut UUD 1945. Teknik pengumpulan data yang digunakan dalam penelitian ini adalah penelitian kepustakaan (library research), yaitu melalui penelusuran peraturan perundang-undangan, dokumendokumen maupun buku-buku, karya tulis ilmiah yang sesuai dengan objek yang akan diteliti. Sumber bahan hukum dalam penelitian ini terdiri bahan-bahan hukum primer dan bahan-bahan hukum sekunder. Bahan hukum primer merupakan bahan hukum yang bersifat autoratif yang artinya mempunyai otoritas. Bahan hukum primer terdiri dari perundang-undangan, catatan resmi atau risalah dalam pembuatan perundangundangan dan putusan-putusan hakim. Sedangkan bahan hukum sekunder berupa semua publikasi yang berkaitan dengan hukum yang bukan merupakan dokumen resmi. $^{7}$

Teknik analisis data dalam penelitian ini adalah mengumpulkan semua bahan hukum, menyeleksi, mengklarifikasi dan menyusun dalam bentuk normatif. Bahan hukum yang sudah terkumpul diolah dan dianalisis dengan teknik interpretasi atau penafsiran hukum yang bertumpu pada penalaran silogisme-deduktif. Menurut Irawan, "analisis data merupakan suatu kegiatan yang bersifat mentransformasikan data menjadi informasi. Data adalah hasil suatu pencatatan, sedangkan informasi adalah makna dari hasil pencatatan". Dengan demikian, teknik analisis yang digunakan dalam penelitian ini yaitu analisis bahan hukum yang bertitik tolak pada peraturan-peraturan yang berlaku sebagai norma hukum positif dan usaha-usaha untuk menemukan asasasas dan informasi baru terkait permasalahan yang diteliti.

\section{PEMBAHASAN}

\section{Mekanisme Pemberhentian Presiden dan atau Wakil Presiden di Indonesia}

Dalam UUD 1945 ataupun UU MK disebutkan MK berkewajiban untuk memutuskan pendapat DPR tentang pemberhentian Presiden dan/atau Wakil Presiden berbeda dengan kewenangan MK dalam kasus yang lain. Atas dasar dan penafsiran atas pemisahan pancantuman ketentuan tersebut bahwa MK memiliki empat kewenangan dan satu kewajiban. Pada ketentuan yang mengatur masalah kewenangan MK disebutkan bahwa MK berwenang mengadili pada tingkat pertama dan terakhir. Selain itu, sifat putusan MK atas empat kewenangan tersebut bersifat final. Sedangkan masalah kewajiban MK hanya disebutkan bahwa MK wajib memberikan putusan. Dengan demikian, yang menjadi pertanyyaan apakah hal ini berarti bahwa kewajiban MK untuk memberi putusan atas pendapat DPR tidak pada tingkat pertama dan terakhir. Adapun putusan MK atas pendapat DPR yang menyatakan Presiden dan/atau Wakil Presiden telah melanggar aturan hukum tidak bersifat final dan mengikat. Artinya akibat hukum dari putusan MK tersebut adalah mendorong terjadinya proses

\footnotetext{
${ }^{6}$ Peter Mahmud Marzuki, Penelitian Hukum, Ed. I, Cet. VII, (Jakarta: Kencana Prenada Media Group, 2011), hlm. 93.

${ }^{7}$ Ibid.., hlm. 141 .
} 
politik di MPR untuk memberhentikan Presiden dan/atau Wakil Presiden yang dinyatakan bersalah oleh Putusan MK. ${ }^{8}$

Kewajiban MK adalah memberi putusan atas pendapat DPR mengenai dugaan pelanggaran oleh Presiden, maka untuk mengerucutkan permasalahan dapat dipahami bahwa masalah-masalah tersebut hanya akan muncul apabila putusan MK adalah membenarkan pendapat DPR. Apabila putusan MK adalah menolak permohonan atau menyatakan permohonan tidak dapat diterima, MK telah menutup segala kemungkinan bagi DPR untuk melanjutkan proses pemberhentian ke MPR. ${ }^{9}$

Namun, apabila MK membenarkan pendapat DPR proses pengambilan keputusan akan bermuara ke MPR dengan cara pengambilan suara terbanyak yang diatur secara rinci dalam UUD 1945 yaitu rapat paripurna MPR harus dihadiri oleh sekurang-kurangnya 3/4 dari seluruh anggota MPR dan harus medapat persetujuan sekurang-kurangnya $2 / 3$ anggota MPR yang hadir dalam rapat paripurna. ${ }^{10}$ Walaupun, perbuatan atau penafsiran atas bentuk-bentuk perbuatan yang diatur dalam UUD tersebut masih merupakan subyek perdebatan dikalangan para pakar.

Pasal 7A UUD 1945 menyebutkan bahwa alasan-alasan pemberhentian adalah pengkhianatan terhadap negara, korupsi, penyuapan, tindak pidana berat lainnya, atau perbuatan tercela; dan/atau pendapat bahwa Presiden dan/atau Wakil Presiden tidak lagi memenuhi syarat sebagai Presiden dan/atau Wakil Presiden. ${ }^{11}$ Penjabaran atas bentuk-bentuk perbuatan sebagai alasan pemberhentian tersebut diatur dalam UU yang mengatur mengenai masalah-masalah itu sebagaimana disebutkan dalam Pasal 10 ayat (3) UU Nomor 24 Tahun 2003 tentang Mahkamah Konstitusi, Pasal 10 ayat (3) huruf a disebutkan bahwa yang dimaksud dengan pengkhianatan terhadap negara adalah tindak pidana terhadap keamanan negara sebagaimana diatur dalam UU. ${ }^{12}$ Mengenai kejahatan terhadap keamanan negara, hal ini diatur dalam KUHP buku II tentang Kejahatan pada Bab I Kejahatan terhadap Keamanan Negara, selain yang terdapat dalam KUHP adalah tindak pidana terorisme sebagaimana diatur dalam (UU Nomor 15 Tahun 2003 tentang Pemberantasan Tindak Pidana Terorisme).

Menurut Wirjono Prodjodikoro, pengkhianatan terhadap negara ada 2 (dua) macam, yaitu:

1. Pengkhianatan intern (hoogveraad) dengan maksud merubah struktur kenegaraan dan pemerintahan yang sudah ada:

2. Pengkhianatan ekstern (landverraad) dengan maksud berbahaya terhadap keamanan negara dari serangan luar negeri. ${ }^{13}$

Setelah UUD 1945 diamademen DPR memiliki 3 (tiga) fungsi yaitu: Pertama, fungsi legislasi, Kedua, fungsi anggaran, Ketiga, fungsi Pengawasan. Dalam hal mengajukan mengajukan usul pemberhentian Presiden dan/atau Wakil Presiden DPR menggunakan fungsi pengawasan. Fungsi pengawasan dari DPR dalam rangka usul pemberhentian Presiden dan/atau Wakil Presiden ini dimulai dari hak menyatakan pendapat yang dimiliki oleh setiap anggota DPR. Mekanisme pengajuan hak menyatakan pendapat ini diatur dalam Pasal 182 sampai dengan Pasal 188 Peraturan

\footnotetext{
${ }^{8}$ Malik, "Telaah Makna Hukum Putusan MK yang Final dan Mengikat ", dalam Jurnal Konstitusi Volume 6, Nomor 1, 2006, hlm. 91-92.

${ }^{9}$ Ibid, hlm. 92.

${ }^{10}$ Laica Marzuki, Laica Marzuki, Dari Timur ke Barat Memandu Hukum, (Jakarta: Setjen dan Kepaniteraan Mahkamah Konstitusi, 2008), hlm. 44.

${ }^{11}$ Ibid, hlm. 40.

12 Pasal 10 ayat (3) huruf a Undang-Undang Nomor 24 Tahun 2003 Tentang MK

13 Wirjono Prodjodikoro, Tindak-Tindak Pidana Tertentu di Indonesia,Ed. III, (Bandung: Refika Aditama, 2003), hlm. 195-196.
} 
Tata Tertib DPR (Keputusan DPR Nomor 15/DPR RI/I/2004-2005). Dalam hal, mengajukan usul menyatakan pendapat minimal harus ada 17 (tujuh belas) orang anggota DPR disampaikan secara tertulis dan dijelaskan tntang pelanggaran yang dilakukan olehh Presiden dan/atau Wakil Presiden serta ditulis nama, tanda tangan pengusul dan nama fraksinya selanjutnya disampaikan kepada pimpinan DPR. Pimpinan DPR memberitahukan kepada anggota DPR atas masuknya usulan tersebut dalam Rapat Paripurna, selanjutnya usul tersebut dibagikan kepada seluruh anggota. ${ }^{14}$ Selanjutnya usulan tersebut dibahas dalam rapat badan Musyawarah untuk menntukan jadwal dan agenda Rapat Paripurna selanjutnya. Dalam Rapat Paripurna kepada pengusul diberikan hak untuk menyampaikan pendapat secara singkat, tepat dan berbobot.

Dalam Rapat Paripurna yang telah ditentukan agendanya pada Rapat Badan Musyawarah, anggota yang mengusulkan pendapat atas tuntutan pemberhentian kepada Presiden dan/atau wakil Presiden diberikan kesempatan untuk memberikan penjelasan atas usulnya. Setiap fraksi diberikan kesempatan untuk menyampaikan pendapat atas usulan tersebut. Kemudian, kepada anggota yang mengusulkan pendapat tuntutan pemberhentian diberikan hak untuk menjawab pandangan fraksi itu. Selanjutnya, dalam Rapat Paripurna memutuskan apakah usulan tersebut secara prinsip dapat diterima atau tidak. Apabila Rapat Paripurna memutuskan menolak usulan tersebut maka tidak dapat diajukan kembali pada masa sidang itu. Namun bila Rapat Paripurna menyetujui usulan tersebut, DPR harus membentuk Panitia Khusus. ${ }^{15}$

Tugas Panitia Khusus melakukan pembahasan dengan Presiden dan atau Wakil Presiden. Dalam melakukan pembahasan atas tuduhan pemberhentian kehadiran Presiden dan/atau Wakil Presiden tidak dapat diiwakili. Hal tersebut berkaitan dengan hak subpoena yang dimiliki Panitia Khusus dalam rangka hak menyatakan pendapat atau hak angket. Hak subpoena merupakan hak yang bisa memanggil secara paksa seseorang yang dirasakan perlu didengar keterangannya dalam penyelidikan yang dilakukan Panitia Khusus. Namun, apabila yang bersangkutan tidak hadir dalam pemanggilan oleh Panitia Khusus maka diancam dengan sandera selama 15 (lima belas) hari. Walaupun, pelanggaran tersebut dilakukan oleh Presiden dan/atau Wakil Presiden, dikarenakan sedang menyelidiki kasus pidana sebagaimana yang dilakukan oleh penyelidik walaupun dalam hal ini adalah DPR. ${ }^{16}$

Dalam hal proses penyelidikan pelanggaran hukum DPR harus menjalankan sesuai dengan mekanisme yang telah diatur dalam tata tertibnya. Selain itu panitia khusus dalam melakukan pembahasannya juga dapat mengadakan Rapat Kerja, Rapat Dengar Pendapat dan/atau Rapat Dengar pendapat Umum dengan pihak yang dianggap perlu, termasuk dengan pengusul. Bahan pengambil keputusan dalam rapat Paripurna untuk menyetujui atau menolak pernyataan tersebut adalah rapat yang dilakukan dengan Panitia Khusus. ${ }^{17}$

Pengambilan keputusan dalam hal tuduhan pemberhentian terhadap Presiden/atau Wakil Presiden pada Rapat Paripurna harus dihadiri oleh sekurangkurangnya $2 / 3$ (dua pertiga) dari anggota yang hadir dalam rapat tersebut. Bila dalam Rapat Paripurna tersebut menyetujui usulan tuduhan pemberhentian terhadap Presiden, maka usulan pendapat tersebut disampaikan kepada MK untuk mendapatkan

\footnotetext{
${ }^{14}$ Ibid, hlm. 81.

${ }^{15}$ Laica Marzuki, Berjalan-Jalan di Ranah Hukum, Cet. 1, (Jakarta : Konstitusi Press, 2005), hlm. 61.

${ }^{16}$ Muhammad Bahrul Ulum, “Mekanisme Pemakzulan Presiden dan/atau Wakil Presiden Menurut UUD 1945 (Antara Realitas Politik dan Penegakan Konstitusi) “, dalam Jurnal Konstitusi, Setretariat Jenderal dan Kepaniteraan MKRI, Volume 7, Nomor 4, Jakarta, 2010, hlm. 20.

${ }^{17}$ Ibid, hlm. 82.
} 
putusan. Apabila MK memutuskan membenarkan pendapat DPR, maka kemudian DPR mengadakan Rapat Paripurna untuk melanjutkan usulan pemberhentian Presiden dan atau Wakil Presiden kepada MPR. ${ }^{18}$

Proses pemberhentian di MK adalah bahwa MK memutus benar atau salahnya pendapat DPR atas tuduhan pemberhentian yang ditujukan kepada Presiden dan/atau Wakil Presiden. Maka ketika proses pemberhentian di MK bukan dalam pelaksanaan mengadili Presiden dan/atau Wakil Presiden atas tuduhan pemberhentian, karena yang menjadi obyek dalam proses pemberhentian di MK adalah pendapat DPR.

MK diwajibkan memeriksa, mengadili dan memberikan putusan atas pendapat DPR. Oleh sebab itu proses pemberhentian di MK adalah untuk melihat tuduhan pemberhentian kepada Presiden dan/atau Wakil Presiden dalam perspektif hukum. Karena MK merupakan institusi peradilan sebagai salah satu pemegang kekuasaan kehakiman, maka putusan yang dijatuhkan MK atas pendapat DPR adalah untuk memberi justifikasi secara hukum. ${ }^{19}$

DPR adalah satu-satunya pihak yang memiliki legal standing untuk beracara di MK dalam rangka tuduhan pemberhentian kepada Presiden dan/atau Wakil Presiden. Dalam Pasal 80 ayat (1) UU Nomor 24 tahun 2003 disebutkan bahwa "Pemohon adalah DPR" yang akan mewakili DPR dalam persidangan di MK atau dapatkah DPR menunjuk kuasa hukum untuk mewakili kepentingannya di persidangan MK. Dalam hal tersebut, UU MK mengatur bahwa setiap pemohon dan/atau termohon dapat didampingi atau diwakili oleh kuasanya. Berarti DPR sebagai pemohon dalam perkara tuduhan pemberhentian di MK juga dapat menunjuk kuasa untuk mendampingi atau mewakilinya dalam beracara di MK. Akan tetapi, dengan pertimbangan untuk memberikan keterangan selengkap-lengkapnya kepada Majelis Hakim Konstitusi tentu lebih baik bilamana DPR menunjuk anggota-anggotanya yang terlibat secara intens dalam rapat-rapat di DPR ketika penyusunan tuduhan pemberhentian. Misalnya anggota-anggota yang mengusulkan hak menyatakan pendapat maupun anggota Panitia Khusus yang dibentuk untuk melakukan pembahasan tuduhan pemberhentian di DPR. ${ }^{21}$

Pelaksanaan proses pemberhentian Presiden dan/atau Wakil Presiden dalam persidangan MK adalah hak bukanlah kewajiban. Hak Presiden dan/atau Wakil Presiden dalam hal tuduhan oleh DPR melakukan pelanggaran hukum untuk memberikan keterangan dalam persidangan MK menurut versinya apabila Presiden dan/atau Wakil Presiden merasa bahwa pendapat ataupun keterangan yang diberikan oleh DPR tidak benar. ${ }^{22}$ Dalam hal menunjukkan kuasa hukum dalam persidangan, Presiden dan/atau Wakil Presiden juga memiliki hak untuk didampingi atau diwakili oleh kuasa hukum sebagaimana DPR. Namun, alangkah lebih bijak bilamana Presiden dan/atau Wakil Presiden hadir dalam persidangan MK sebagaimana Presiden dan/atau Wakil Presiden hadir dalam memberikan keterangan dalam rapat pembahasan Panitia Khusus yang dibentuk oleh DPR sebagaimana diatur dalam Peraturan Tata Tertib (Tatib) DPR.

\footnotetext{
${ }^{18}$ Laica Marzuki, Berjalan-Jalan di Ranah Hukum, Op Cit, hlm. 45.

${ }^{19}$ Ibid, hlm. 46.

${ }^{20}$ Pasal 80 ayat (1) UU Nomor 23 tahun 2004 tentang Mahkamah Konstitusi

${ }^{21}$ Ahmad Fadlil Sumadi, "Hukum Acara MK dalam Teori dan Praktek ", dalam Jurnal Konstitusi, Volume 8 Nomor 6, Jakarta, 2011, hlm. 875.

22 Ibid, hlm. 876 .
} 
Syarat formil permohonan berarti permohonan tersebut harus mencantumkan hal-hal yang harus dipenuhi diluar dari substansi perkara. Sedangkan pokok perkara berarti permohonan tersebut harus menguraikan secara jelas substansi perkara dan halhal yang dimohon untuk diputus dalam hal ini yaitu benar atau salahnya pendapat bahwa Presiden dan/atau Wakil Presiden telah malakukan pelanggaran hukum berupa pengkhianatan terhadap negara, korupsi, penyuapan, tindak pidana berat lainnya, atau perbuatan tercela; dan/atau pendapat bahwa Presiden dan/atau Wakil Presiden tidak lagi memenuhi syarat sebagai Presiden dan/atau Wakil Presiden. ${ }^{23}$

Dalam perkara perselisihan hasil pemilu, pengujian UU terhadap UUD, sidang pemeriksaannya dilakukan dengan sidang panel. Sedangkan untuk perkara memutus pendapat DPR atas tuduhan pemberhentian kepada Presiden dan atau Wakil Presiden belum dibuat ketentuan apakah akan tetap menggunakan panel hakim ataukah langsung sidang pleno.

Dalam hal pelaksanaan kewajiban memutus pendapat DPR atas tuduhan pemberhentian kepada Presiden dan/atau Wakil Presiden, UU MK menambah satu persyaratan formil yang harus dipenuhi oleh DPR yaitu bahwa DPR harus memenuhi prosedur pengambilan keputusan atas tuduhan pemberhentian sesuai dengan UUD 1945 (Pasal 7B ayat (3) serta Peraturan Tata Tertib. Persyaratan formil secara jelas diatur dalam Pasal 80 ayat (3) UU No. 24 Tahun 2003 tentang Mahkamah Konstitusi, bahwa pemohon wajib menyertakan keputusan DPR dan proses pengambilan keputusan yang diatur dalam Pasal 7B ayat (3) UUD 1945, risalah dan/atau berita acara ${ }_{24}$ apat DPR serta bukti atas tuduhan pemberhentian Presiden dan/atau Wakil Presiden.

Dalam hal pemeriksaan syarat formil permohonan memutus pendapat DPR atas tuduhan pemberhentian kepada Presiden dan/atau Wakil Presiden, maka ada 3 (tiga) persyaratan yang harus dipenuhi yaitu (i) legal standing, (ii) kewenangan MK untuk mengadili dan (iii) prosedural yang harus dipenuhi oleh DPR dalam mengambil keputusan atas pendapat yang diajukan. Konsekuensinya apabila salah satu persyaratan ini tidak dipenuhi, maka amar putusan MK akan menyatakan bahwa permohonan tidak dapat diterima. ${ }^{25}$

UUD 1945 dan UU Nomor 8 tahun 2011 tentang MK seolah membuat klasifikasi pokok perkara tuduhan pemberhentian kedalam 2 (dua) kelompok yaitu (a) Presiden dan/atau Wakil Presiden melakukan pelanggaran hukum dan (b) Presiden dan/atau Wakil Presiden tidak lagi memenuhi syarat sebagai Presiden dan/atau Wakil Presiden. Sedangkan pelanggaran hukum dalam kelompok pertama adalah berupa pengkhianatan terhadap negara, korupsi, penyuapan, tindak pidana berat lainnya atau perbuatan tercela. Sedangkan yang termasuk dalam kelompok kedua yaitu syarat sebagai Presiden dan atau Wakil Presiden adalah sebagaimana ditentukan dalam Pasal 6 ayat (1) UUD 1945 serta Pasal 6 ayat (2) UUD 1945.

Walaupun demikian pengelompokkan ini tidak membawa dampak hukum yang berbeda. Karena bilamana Presiden dan/atau Wakil Presiden terbukti melakukan salah satu dari perbuatan melanggar hukum sebagaimana termasuk dalam kelompok pertama maupun Presiden dan/atau Wakil Presiden terbukti tidak lagi memenuhi syarat sebagai Presiden dan/atau Wakil Presiden sebagaimana termasuk dalam kelompok

\footnotetext{
23 Jimly Asshiddiqie, Sengketa Kewenangan Konstitusional Lembaga Negara, (Jakarta: Konstitusi Press, 2006),, hlm. 200.

${ }^{24}$ Ibid, hlm. 202

${ }^{25}$ Pasal 83 UU Nomor 24 tahun 2003 tentang Mahkamah Konstitusi
} 
kedua, maka amar putusan MK adalah membenarkan pendapat DPR. Namun bila Presiden dan/atau Wakil Presiden tidak terbukti melakukan pelanggaran hukum dan/atau tidak terbukti tidak lagi memenuhi syarat sebagai Presiden dan/atau Wakil Presiden maka amar putusan MK adalah menyatakan permohonan ditolak.

UU MK memberikan batasan waktu 90 hari, setelah permohonan didaftar pada Buku Registrasi Perkara Konstitusi di kepaniteraan, bagi MK untuk memutus pendapat DPR mengenai tuduhan pemberhentian kepada Presiden dan/atau Wakil Presiden. Selama kurun waktu itu ada beberapa tahapan persidangan yang harus dilakukan MK sebelum mengambil putusan. Tahapan sidang pertama yaitu pemeriksaan pendahuluan, tahapan sidang kedua yaitu pemeriksaan persidangan yang didalamnya termasuk sidang pembuktian sebelum akhirnya digelar sidang pembacaan putusan sebagi tahapan akhir. ${ }^{26}$

Pada pelaksanaan hukum acara kewenangan MK yang lain, sidang pemeriksaan pendahuluan dilakukan oleh sidang panel hakim yang terdiri dari tiga (3) orang. Sidang pemeriksaan pendahuluan adalah memeriksa kelengkapan dan kejelasan materi permohonan sebelum masuk dalam pemeriksaan pokok perkara. Pada tahapan tersebut majelis hakim wajib memberi nasihat kepada pemohon untuk melengkapi atau memperbaiki permohonan. ${ }^{27}$ Berkaitan dengan permohonan dalam perkara memutus pendapat DPR atas tuduhan pemberhentian (pemberhentian) kepada Presiden dan/atau Wakil Presiden, maka hal-hal yang perlu diperiksa pada tahapan pemeriksaan pendahuluan adalah syarat-syarat formil dan kelengkapan administrasi yang meliputi.

1. Legal Standing

Majelis hakim wajib memeriksa pemohon dalam perkara ini adalah DPR atau kuasa yang ditunjuk oleh DPR.

2. Kewenangan MK untuk mengadili perkara

Majelis hakim memeriksa apakah betul perkara yang diajukan oleh pemohon termasuk dalam kewenangan MK untuk memeriksa, mengadili dan memutus perkara ini. ${ }^{28}$

3. Prosedur pengambilan keputusan DPR

Majelis hakim wajib memeriksa proses pengambilan keputusan DPR atas pendapat bahwa Presiden dan/atau wakil Presiden telah melakukan pelanggaran hukum dan/atau tidak lagi memenuhi syarat sebagai Presiden dan/atau Wakil Presiden telah sesuai dengan prosedur yang diatur dalam Pasal 7B ayat (3) UUD 1945 dan Peraturan Tata Tertib DPR. Dalam rangka memenuhi hal ini maka permohonan DPR menyertakan (i) keputusan DPR, (ii) risalah sidang DPR dan (iii) berita acara rapat DPR yang berkaitan dengan proses pengambilan keputusan sebagaimana diatur dalam Pasal 7B UUD 1945 dan Peraturan Tata Tertib DPR.

4. Bukti-bukti

Majelis hakim wajib memeriksa apakah bukti yang diajukan oleh DPR dalam permohonan telah memadai untuk melakukan proses pemberhentian di MK. MK juga menetapkan standar bukti permulaan yang cukup sehingga proses pemeriksaan pendapat DPR dapat dilanjutkan pada tahap berikutnya. Mengenai standar bukti permulaan dalam hal ini, MK mengacu pada standar bukti dalam hukum acara pidana

\footnotetext{
${ }^{26}$ Feri Amsari, “Masa Depan MK Kesesuaian Teori dan Implementasi “, dalam Jurnal Konstitusi Vol 5, Jakarta, 2008. hlm. 90-91.

${ }^{27}$ Jimly Asshiddiqie, Sengketa Kewenangan Konstitusional Lembaga Negara, Op Cit, hlm. 203.

28 Ahmad Fadlil Sumadi, Hukum Acara MK dalam Teori dan Praktek ", dalam Jurnal Konstitusi, Volume 8 Nomor 6, Jakarta, 2011, hlm. 1876.
} 
mengingat bahwa tuduhan pemberhentian merupakan perbuatan pidana yang dilakukan oleh Presiden dan/atau Wakil Presiden.

MK wajib menetapkan jumlah bukti sesuai yang diajukan oleh DPR dalam permohonannya. Pasal 183 KUHAP ditentukan bahwa baru bisa dijatuhkan pidana kepada seseorang, sekurang-kurangnya dibutuhkan 2 (dua) dari 5 (lima) jenis alat bukti yang sah. ${ }^{29}$ Apakah MK juga harus menetapkan bahwa DPR harus ada minimal 2 (dua) alat bukti dalam permohonannya atau harus lebih? Mengingat bahwa kasus pemberhentian Presiden merupakan kasus khusus yang membutuhkan penanganan dan persyaratan yang istimewa. Pasal 184 ayat (1) KUHAP menyebutkan alat-alat bukti yang sah adalah:
a. keterangan saksi;
b. keterangan ahli;
c. surat;
d. petunjuk;
e. keterangan terdakwa. ${ }^{30}$

Mengacu pada Kitab Undang-Undang Hukum Acara Pidana (KUHAP) maka timbul permasalahan yaitu apakah keterangan saksi dan/atau ahli yang disampaikan dalam Rapat Panitia Khusus DPR dapat digolongkan pada alat bukti yang sah. Hal tersebut mengingat bahwa saksi dan ahli hanya dapat legitimasi didepan sidang. Apakah rapat panitia khusus DPR termasuk sebagai sidang yang dapat mengangkat saksi dan ahli tersebut. UU Mahkamah Konstitusi mengatur bahwa apabila pemohon ingin mengajukan saksi dan/atau ahli dalam persidangan maka biodata saksi dan/atau ahli dapat dilampirkan dalam permohonan. Namun lampiran pengajuan nama saksi dan/atau ahli tidaklah termasuk dalam kualitas alat bukti yang harus dilampirkan dalam permohonan DPR. Keterangan saksi dan/atau ahli yang diajukan pemohon tersebut menjadi alat bukti bagi majelis hakim untuk menjatuhkan putusan.

Ketentuan yang mengacu pada jenis alat bukti yang sah menurut KUHAP maka kemungkinannya hanya ada 2 (dua) jenis alat bukti yang sah yang dapat diajukan DPR dalam permohonannya dimana alat bukti tersebut sangat kuat yang tidak bisa menimbulkan perdebatan yaitu alat bukti surat dan alat bukti petunjuk. Dengan demikian bila mengacu pada KUHAP, pada Pasal 187 KUHAP yang disebut surat adalah surat yang dibuat atas sumpah jabatan atau dikuatkan dengan sumpah, yaitu:

a. Berita acara dan surat lain dalam bentuk resmi yang dibuat oleh pejabat umum yang berwenang atau yang dibuat oleh pejabat umum yang berwenang atau yang dibuat dihadapannya, yang memuat keterangan tentang kejadian atau keadaan yang didengar, dilihat atau yang dialaminya sendiri, disertai dengan alasan yang jelas dan tegas tentang keterangannya itu;

b. Surat yang dibuat menurut ketentuan peraturan perundang-undangan atau surat yang dibuat oleh pejabat mengenai hal yang termasuk dalam tata laksana yang menjadi tanggung jawabnya dan yang diperuntukkan bagi pembuktian sesuatu hal atau suatu keadaan;

\footnotetext{
${ }^{29}$ Undang-Undang Nomor 8 Tahun 1981 Tentang Kitab Undang-Undang Hukum Acara Pidana

${ }^{30}$ Wirjono Prodjodikoro, Tindak-Tidak Pidana Tertentu di Indonesia, Op Cit, hlm. 198.
} 
c. Surat keterangan dari seorang ahli yang memuat pendapat berdasarkan keahliannya mengenai sesuatu hal atau suatu keadaan yang diminta secara resmi daripadanya; ${ }^{31}$

Dalam kaitannya dengan proses pemberhentian, mungkin saja DPR menemukan keputusan atau surat penetapan yang dikeluarkan Presiden dan/atau Wakil Presiden yang mengarah pada tuduhan pemberhentian. Temuan DPR pada keputusan atau surat penetapan tersebut dapat dijadikan alat bukti bagi permohonan ke MK. Dengan demikian, maka berita acara rapat pansus DPR dapat dijadikan alat bukti surat untuk dilampirkan pada permohonan.

Hal ini sama dengan berita acara sebagaimana disebutkan dalam huruf (a). Berita acara rapat pansus DPR yang dihadirkan ahli untuk dimintai keterangannya dalam rapat pansus dapat dijadikan alat bukti surat. Sedangkan yang disebut alat bukti petunjuk, dengan merujuk pada Pasal 188 ayat (1) KUHAP adalah perbuatan, kejadian atau keadaan yang karena persesuaian, baik antara yang satu dengan yang lain, maupun dengan tindak pidana itu sendiri, menandakan bahwa telah terjadi suatu tindak pidana dan siapa pelakunya.

Pemeriksaan untuk selanjutnya apakah dalam permohonan telah dicantumkan daftar nama calon saksi dan calon nama ahli. Daftar calon nama ini menjadi sangat penting mengingat prosedur beracara dalam memutuskan pendapat DPR ini dibatasi oleh waktu, selain itu karena keterangan yang diberikan oleh saksi ataupun ahli merupakan bahan pertimbangan yang berharga mengingat proses beracara di MK dalam rangka memutus pendapat DPR ini bersifat adversarial.

Pemeriksaan persidangan dilakukan dalam sidang pleno Majelis Hakim. Dalam persidangan majelis hakim memeriksa permohonan beserta alat bukti yang diajukan. Pada Pasal 41 ayat (2) UU MK yang mengatur secara umum mengenai pemeriksaan persidangan disebutkan bahwa demi kepentingan pemeriksaan maka majelis hakim wajib untuk memanggil pihak-pihak yang berperkara untuk memberi keterangan yang dibutuhkan. Selain itu, demi kepentingan pemeriksaan majelis hakim juga wajib meminta keterangan secara tertulis kepada lembaga negara yang terkait dengan permohonan.

Dalam kaitan dengan permohonan pendapat DPR ini maka DPR sebagai pemohon wajib hadir dalam setiap sidang pemeriksaan permohonan pendapat DPR yang digelar oleh MK. Hal ini selain untuk melindungi kepentingan DPR sebagai pemohon dengan mengetahui perkembangan perkara juga agar DPR dapat senantiasa dimintai keterangan yang berkaiatan dengan perkara ini Presiden dan/atau Wakil Presiden sebagai pihak yang sangat berkaitan dengan acara perkara ini, sebagaimana kita ketahui bahwa peradilan MK bersifat adversarial dan kehadiran Presiden dan/atau Wakil Presiden dalam persidangan MK bukan merupakan suatu keharusan, namun demikian kehadiran Presiden dan/atau Wakil Presiden dalam persidangan amatlah penting untuk menjaga kepentingan Presiden dan/atau Wakil Presiden. ${ }^{32}$

Kewajiban MK dalam memberikan putusan atas pendapat DPR mengenai dugaan pelanggaran Presiden sebagaimana menurut Pasal 24C ayat (3), maka dalam hal putusan yang dijatuhkan oleh MK adalah bersifat kondemnatoir artinya putusan tersebut harus dilaksanakan oleh para pihak. Akan tetapi dalam putusan pemberhentian Presiden, dikarenakan terbukti melakukan pelanggaran hukum, walaupun MK disini

\footnotetext{
${ }^{31}$ Jimly Asshiddiqie, Mekanisme Impeachment dan Hukum Acara Mahkama Konstitusi” Kerjasama Mahkamah Konstitusi Republik Indonesia dengan Konrad Adenauer Stiftung, Laporan Penelitian, Jakarta, 2005, hlm. 48.

${ }^{32}$ Ibid. hlm. 50
} 
sebagai lembaga yuridis, akan tetapi putusan MK terhadap pemberhentian Presiden tidak serta merta untuk melakukan eksekusi hasil putusan tersebut.

Pasal 47 UU MK menyatakan bahwa putusan MK memperoleh kekuatan hukum tetap sejak selesai diucapkan dalam sidang pleno yang terbuka untuk umum yang bersifat final dan tidak ada upaya hukum lain karena MK mengadili tingkat pertama dan terakhir. Maka disini putusan MK menganut kepada asas putusan yang berkekuatan hukum tetap dan final, artinya setiap putusan yang dilakukan oleh MK, tidak ada upaya-upaya hukum baik itu banding, kasasi maupun peninjauan kembali.

Walaupun MK telah memutuskan bahwa Presiden bersalah, akan tetapi pelaksanaan wewenang eksekusi dilakukan oleh lembaga lain, adalah lembaga eksekutif atau DPR sebagaimana menurut ketentuan Pasal 7B ayat (5) UUD NRI 1945. MK dalam kewajibannya memberikan putusan atas usulan pendapat DPR, bahwa Presiden telah melanggar konstitusi, untuk selanjutnya DPR melanjutkan ke MPR. Dengan demikian sifat putusan MK yang pertama dan terakhir yang bersifat final serta mengikat menjadi bahan yuridis bagi pelaksanaan oleh MPR. ${ }^{33}$

Putusan MK yang bersifat final dan mengikat dalam pemberhentian Presiden dapat mengikat secara yuridis, artinya putusan tersebut mempunyai kekuatan hukum tetap untuk sepenuhnya kepada MPR sebagai lembaga pertemuan dua kamar legislatif, sehingga MPR sebagai lembaga yang diberikan wewenang untuk melakukan eksekusi (executable forum) dari hasil putusan MK. Dengan demikian putusan MK atas usulan DPR terhadap pelanggaran yang dilakukan oleh Presiden kekuatan eksekusi terhadap pemberhentian Presiden diserahkan sepenuhnya kepada MPR. ${ }^{34}$

\section{Kekuatan Putusan Mahkamah Konstitusi dalam Pemberhentian Presiden dan atau Wakil Presiden dalam Masa Jabatannya}

Putusan Mahkamah Konstitusi (MK) atas pendapat Dewan Perwakilan Rakyat (DPR) tentang pemberhentian Presiden dan atau Wakil Presiden pada masa jabatannya merupakan kewajiban, dimana sifat putusannya pada perkara ini berbeda dengan kewenangan pada persoalan yang lain. Hal tersebut sebagaimana dapat dilihat dalam rumusan Pasal 10 Undang-Undang Mahkamah Konstitusi yang disalin dari Pasal 24c ayat (1) dan (2) UUD 1945 yang berbunyi :

"Ayat (1): Mahkamah Konstitusi berwenang mengadili pada tingkat pertama dan terakhir yang putusannya bersifat final untuk menguji undang-undang terhadap Undang-Undang Dasar, memutus sengketa kewenangan lembaga negara yang kewenangannya diberikan oleh Undang-Undang Dasar, memutus pembubaran partai politik, dan memutus perselisihan tentang hasil pemilihan umum.

Ayat (2): Mahkamah Konstitusi wajib memberikan putusan atas pendapat Dewan Perwakilan Rakyat mengenai dugaan pelanggaran oleh Presiden dan/atau Wakil Presidenmenurut Undang-Undang Dasar."

Dalam ayat (2) dinyatakan bahwa MK hanya wajib memberikan putusan atas pendapat DPR tentang pelanggaran hukum yang dilakukan oleh Presiden dan atau Wakil Presiden, dimana hal tersebut tidak disebutkan secara jelas dalam peraturan perundang-undangan sehingga menyebabkan putusan MK masih boleh ditnjau kembali dan tidak mempunyai kekuatan hukum secara mengikat. Berbeda halnya putusan MK tentang perselisihan hasil pemilu, menguji undang-undang, pembubaran partai Politik, dan memutuskan sengketa kewenangan lembaga negara yang bersifat final. Namun, dalam Pasal 24 ayat (1) UUD 1945 disebutkan "bahwa kekuasaan

\footnotetext{
${ }^{33}$ Feri Ansari, Masa Depan MK, Kesesuaian Teori dan Implementasi, Op Cit, hlm. 91.
}

${ }^{34}$ Ibid, hlm. 92. 
kehakiman merupakan kekuasaan yang merdeka" dan dalam Pasal 1 ayat (3) UUD 1945 dinyatakan bahwa "Indonesia merupakan negera hukum".

Dengan demikian, bahwa putusan MK tentang pemberhentian Presiden dan atau Wakil Presiden dinilai unik, disebabkan tidak mempunyai hukum mengikat bagi MPR untuk mengikuti putusan MK kecuali dalam hal penyelenggaraan Rapat Paripurna sebagai usulan dari DPR. Hal tersebut sebagaimana kita lihat dalam UUD dan UU Mahkamah Konstitusi yang membedakan antara wewenang dan kewajiban. Hal tersebut, dapat dilihat dari pengaturannya yang diatur dalam ayat yang berdeda. Disebutkan bahwa Mahkamah Konstitusi berwenang mengadili pada tingkat pertama dan terakhir. Selain itu, sifat putusan Mahkamah Konstitusi atas empat kewenangannya yang diatur dalam ayat (1) tersebut bersifat final. Sedangkan ketentuan yang mengatur tentang kewajibannya hanya disebutkan bahwa Mahkamah Konstitusi wajib memberikan putusan. Muncul pertanyaan, apakah kewajiban Mahkamah Konstitusi untuk memberi putusan atas pendapat DPR tidak pada tingkat pertama dan terakhir yang bersifat final?

Maka, dalam hal tersebut timbul bermacam pendapat pakar dalam menafsirkan pertanyaan di atas. Pendapat pertama, menurut Maruarar Siahaan dalam bukunya bahwa memutuskan usulan DPR atas pelanggaran hukum yang dilakukan oleh Presiden dan atau Wakil Presiden merupakan kewajiban MK. Kewajiban MK dalam hal tersebut tetap bersifat mengikat dalam artian bahwa putusan MK tetap merupakan peradian pertama dan terakhir secara yuridis, dikarenakan dalam aturan perundangundangan di Indonesia tidak ada satupun lembaga negara yang diberikan wewenang untuk melakukan review atas putusan yang telah ditetapkan oleh MK. ${ }^{35}$

Pendapat yang kedua mengenai kewajiban MK yang berkaitan dengan mekanisme pemberhentian Presiden dan/atau Wakil Presiden, ada yang berpandangan bahwa peran serta MK tersebut hanya sebatas kewajiban dan bukan wewenang, sebagaimana yang dikemukakan Abdul Latif. Menurut beliau, alasan dikatakan sebagai suatu kewajiban dikarenakan putusan MK dalam hal pemberhentian Presiden dan/atau Wakil Presiden tidaklah final dan dapat dianulir oleh keputusan MPR. Namun, apabila terjadi pemberhentian dikarenakan kepentingan politik maka upaya untuk mewujudkan negara hukum yang demokratis dan konstitusional di Indonesia akan sulit terwujud. ${ }^{36}$ Putusan MK berkaitan dengan pemberhentian Presiden dan/atau Wakil Presiden tidak bersifat final juga dikemukakan oleh Ni'matul Huda. Menurut beliau putusan MK tersebut bukan merupakan putusan final karena pemberhentian Presiden dan/atau Wakil Presiden tetap bermuara pada putusan MPR sebagai lembaga politik yang berwenang. ${ }^{37}$

Proses peradilan yang diselenggarakan oleh MK dalam hal pemberhentian Presiden dan/atau Wakil Presiden dalam pandangan Soimin dan Mashuriyanto bertujuan untuk mendapatkan kekuatan hukum terkait pemberhentian Presiden dan/atau wakil presiden dalam negara konstitusional, sehingga dapat berlangsung checks and balances system dalam sistem ketatanegaraan Indonesia. Meskipun demikian lebih lanjut dikemukakan bahwa pemberhentian Presiden dan/atau Wakil Presiden tidak sepenuhnya dikarenakan proses peradilan, sebab putusan akhir mengenai pemberhentian tersebut berada pada parlemen (MPR) sebagai lembaga

\footnotetext{
35 Maruarar Siahaan, Hukum Acara mahkamah Konstitusi Republik Indonesia, (Jakarta: Sinar Garafika), 2011, h. 13.

${ }^{36}$ Abdul Latif, Fungsi Mahkamah Konstitusi (Upaya Mewujudkan Negara Hukum Demokrasi), (Jakarta: Kreasi Total Media, 2009), hlm. 164.

${ }^{37}$ Ni'matul Huda, UUD 1945 dan Gagasan Amandemen Ulang, (Jakarta: Rajawali Press, 2008), hlm. 254.
} 
politik yang akan memutuskan pemberhentian presiden dan/atau wakil presiden. ${ }^{38}$ Checks and balances sendiri dalam pemisahan kekuasaan diperlukan untuk mengatur, membatasi, dan mengendalikan kekuasaan negara dengan sebaik-baiknya agar penyalahgunaan kekuasaan oleh penyelenggara negara dapat dicegah dan ditanggulangi. ${ }^{39}$ Dengan demikian pula dalam hal pemberhentian Presiden dan/atau Wakil Presiden, dimana kewenangan MK sebagai bentuk checks and balances terhadap DPR yang bertujuan untuk mencegah upaya politisasi dalam pemberhentian presiden dan/atau wakil presiden yang didasarkan pada pertimbangan politik semata seperti adanya konflik kepentingan antara presiden dan/atau wakil presiden dengan kekuatan mayoritas politik di DPR.

Peran MK dalam pemberhentian presiden dan/atau wakil presiden berkaitan dengan upaya checks and balances terhadap lembaga negara lainnya (DPR dan Presiden dan/atau Wakil Presiden) juga dikemukakan oleh Partialis Akbar. Dalam pandangan beliau MK berperan sebagai lembaga upaya DPR tersebut untuk mengadili apakah alasan pemberhentian Presiden dan/atau Wakil Presiden benar menurut hukum atau konstitusi, bukan hanya merupakan bentuk ketidaksepahaman (konflik) DPR terhadap presiden dan/atau wakil presiden berkaitan dengan persaingan politik belaka. ${ }^{40}$ Dengan kata lain MK akan menerapkan pendekatan hukum untuk mengadili pendapat DPR terkait alasan pemberhentian Presiden dan/atau Wakil Presiden, yang sebelumnya diambil melalui pendekatan politik di DPR. ${ }^{41}$ Selain menajalankan fungsi checks and balances terhadap DPR, peran MK dalam pemberhentian presiden dan/atau wakil presiden juga merupakan titik singgung hubungan antara MK dan presiden atau wakil presiden. ${ }^{42}$

Dengan demikian, wewenang dan kewajiban adalah untuk membedakan antara putusan MK yang bersifat final dan tidak. Jadi menurut pendapat yang kedua putusan MK yang bersifat final adalah yang diberikan wewenang oleh undang-undang yaitu menyangkut, pengujian undang-undang, sengketa kewenangan lembaga negara, perselisihan hasil pemilihan umum dan pembubaran partai politik. Namun, terkait dengan kewajiban memberikan putusan atas pendapat DPR adalah putusan MK tidak bersifat final dan masih bisa dipersoalkan oleh MPR, disebabkan dalam Pasal 7B ayat (7) UUD 1945 disebutkan, bahwa Presiden dan atau Wakil Presiden masih diberikan kesemptatan menyampaikan penjelasan mengenai tuduhan yang dituduh oleh DPR dan diputuskan oleh MK dalam rapat sidang Paripurna MPR. Dengan demikian, putusan hukum yang telah diputuskan oleh MK belum dianggap sebagai suatu putusan yang bersifat final untuk memberhentikan Presiden dan atau Wakil Presiden. Oleh sebab itu, putusan akhir dalam hal pemberhentian Presiden dan atau Wakil Presiden berada ditangan MPR. ${ }^{43}$

Menurut penulis, dari dua pendapat diatas lebih condong kepada pendapat pertama disebabkan beberapa alasan yang pertama dalam Pasal 1 ayat (3) UUD 194 dinyatakan bahwa Indonesia adalah negara hukum, Pasal 24 ayat (1) UUD 1945 disitu disebutkan bahwa kekuasan kehakiman merupakan kekuasaan yang merdeka untuk menyelenggarakan peradilan dengan maksud menegakkan hukum dan keadilan.

\footnotetext{
38 Soimin dan Mashuriyanto, Mahkamah Konstitusi dalam Sistem Ketatanegaraan Indonesia, (Yogyakarta: UII Press, 2013), hlm. 160.

${ }^{39}$ Ni'matul Huda, Hukum Tata Negara Indonesia, (Jakarta: PT. Raja Grafindo Persada, 2007), hlm. 107.

${ }^{40}$ Patrialis Akbar, Lembaga-Lembaga Negara menurut UUD NRI 1945, (Jakarta: Sinar Grafika, 2013), hlm. 181-182.

${ }^{41}$ Ibid., hal. 235.

${ }^{42}$ Ibid., hlm. 228.

${ }^{43}$ Ibid. h. 230-231.
} 
Dengan demikian, maka proses peradilan mempunyai hukum tetap dan mengikat, meskipun dalam UU Mahkamah Konstitusi disitu disebutkan bahwa yang bersifat final putusan MK hanya pada empat kewenangan, sedangkan pada proses pemberhentian Presiden pada ayat (2) tidak disebutkan secara jelas. Namun dalam hal ini untuk menentukan putusan tersebut bersifat final ataupun tidak adalah dengan diberikan kewenangan kepada suatu lembaga untuk bisa melakukan review terhadap putusan putusan pengadilan yang sudah diputuskan serta ada tidaknya dalam hukum acara yang mengatur tentan siapa dan bagaimana cara peninjauan ulang putusan yang telah diputusakan oleh MK. Sebenarnya untuk ukuran kedua pendapat tersebut tidak ditemukan secara baik dalam UUD ataupun UU Mahlmah Kontitusi. Dengan demikian, menurut penulis tentang pemberhentian Presiden dan atau Wakil Presiden secara hukum telah bersifat final hal tersebut juga dikuatkan dengan Pasal 47 UU Mahkamah Konstitusi yang mengatakan bahwa putusan MK memperoleh kekuatan hukum tetap sejak selesai diucapkan dalam sidang pleno terbuka untuk umum.

Selain itu, menurut pendapat Sri Soemantri, bahwa putusan yang telah bersifat final harus bersifat mengikat dan tidak bisa dianulir oleh lembaga manapun. selanjutnya, apabila kita mengacu pada pendapat Van Apeldoorn, bahwa hukum tidak hanya terbatas pada peraturan perundang-undangan yang berlaku dan mengikat namun juga bisa menjelmadalam putusan hakim yang juga bersifat mengatur dan memaksa, maka sangat tepat bahwa putusan MK tersebut bersifat final dan mengikat yang putusannya membenarkan pendapat DPR, dan selanjutnya MPR sebagai lembaga yang berwenang memberhentikan Presiden dan atau Wakil Presiden dalam masa jabatanya harus mengikuti putusan MK. ${ }^{44}$

Menurut Suwoto Mulyosudarmo ${ }^{45}$ tentang masalah pemberhentian Presiden dan atau Wakil Presiden dia mengemukakan pendapatnya saat sebelum dan disahan perubahan Ketiga UUD 1945. Beliau berpendapat bahwa prose peradilan untuk memberhentikan presiden atas dasar putusan Mahkamah Agung karena melakukan tindak pidana kejahatan. Kasus kejahatan yang dilakukan oleh Presiden dan atau wakil Presiden jangan diputuskan olh MK dan peradilan tersebut juga tidak dibenarkan diputuskan oleh MPR, disebabkan MPR merupakan lembaga politik sedangkan MK adalah lembaga untuk mengunju undang-undang. Dalam proses pelaksanaan pemberhentian Presiden DPR diberikan kewenangan untuk melakukan dakwaan kriminal yang dilakukan oleh Presiden setelah mendapatkan akpek yuridis dari lembaga independen. ${ }^{46}$ Selanjutnya, DPR menyerhkan kepada MPR untuk diserahkan kepada MA. Jadi, MA yang diberikan hak untuk memeriksa dan memutuskan pada tingkat pertama dan terakhir dalam kasus tersebut. Berdasrakan putusan MA tersebut MPR memutuskan pemberhentian Presiden. ${ }^{47}$

Proses hukum dalam perkara pemberhentian Presiden adan atau Wakil Presiden agar tidak sewenang-weang dan dilakukan secara transparan dan tidak menimbulkan persolan yang baru. Misalnya tidak ada jaminan putusan MK yang menyatakan bahwa Presiden dan atau Wakil Presiden bersalah maka harus diikuti oleh MPR. Namun, apabila MPR tidak mau mengikuti putusan MK dengan berpedoman kepada perndapat yang pertama diatas, maka wibawa MK selaku institusi huum tentunya akan jatuh. Dengan demikian, sebenarnya putuasn MK harus memiliki akibat hukum karena

\footnotetext{
${ }^{44}$ Van Apeldoorn, Pengantar Ilmu Hukum, Cet. 24, (terjemahan Oetarid Sadino), Jakarta: PT Pradnya Paramita. Terjemahan dari Inleiding Tot de Studie van het Nederlandse Recht, 1990, h. 4-5.

45 Soewoto Mulyosudarmo, Pembaharuan Ketatanegaraan Melalui Perubahan Konstitusi, Malang: Asosiasi Pengajar HTN dan HAN Jawa Timur dan In- Trans, 2004, h. 32.

${ }^{46}$ Ibid. h. 33.

${ }^{47}$ Ibid. h. 34.
} 
dalam pembuktian sesuai dengan prinsip hukum acara pidana, akan menjadi tidak tegas saat dianuli oleh MPR. Betitu juga, disaat MPR mengikuti putusan MK, namun yang menjadi persoalan disaat mantan Presiden dan atau Wakil Presiden menjalani proses di pengadian umum yang ternyata putusan pengadilan umum berbeda dengan putusan MK. Tentu kresibilitas MK dan MK sebagai dua institusi hukum dipertanyakan.

\section{KESIMPULAN}

Indonesia sebagai negara hukum yang tertuang Pasal 1 ayat (3) UUD 1945, maka kedudukan proses hukum terletak di akhir dari rangkaian proses pemberhentian Presiden dan atau Wakil Presiden untuk terwujudnya negara hukum sebagaimana diamanat dalam UUD 1945. Maka dalam hal pemberhentian Presiden dan atau Wakil Presiden kekuatan putusan MK bersifat final dan mengikat secara hukum, walaupun dalam hal pemberhentian Presiden dan atau Wakil Presiden merupakan kewajiban bukan wewenang dalam hal putusan, disebabkan tidak aturan hukum yang mengatur untuk bisa review putusan yang telah diputuskan oleh MK oleh lembaga manapun. Namun, dalam hal pemberhentian Presiden dan atau Wakil Presiden harus ada penegasan yang jelas tentang aturan yang dimuat dalam Pasal 24c ayat (1) dan (2) terkait kewajibannya yang merupakan kewajiban kontistusional dalam memutuskan perkara tersebut, yang masih terjadi perbedaan pendapat para ahli hukum. Maka saran penulis, MPR sebagai lembaga negara yang bisa melakukan amandemen UUD 1945 untuk tidak membedakan antara wewenang dan kewajiban yang mengakibatkan multi tafsir dan memperjelas terhadap Pasal 7B ayat (7) yang diputuskan oleh MPR dengan pengambilan suara terbanyak dalam sidang paripurna, dengan demikian mencerminkan bahwa putusan hukum bisa berubah oleh kepentingan politik.

\section{SARAN}

Perubahan terhadap Pasal 7A, 7B, dan Pasal 24C ayat (2) UUD 1945 diperlukan mengingat mengingat dalam Pasal tersebut masih menyisakan masalah tentang hal pemberhentian Presiden dan atau Wakil Presiden di Indonesia. Oleh sebab itu penulis menyarankan bahwa : (1) Pada kata kewajiban Mahkamah Konstitusi wajib memberikan putusan atas pendapat Dwan Perwakilan mengenai dugaan pelanggaran oleh Presiden dan/atau Wakil Presiden sebaiknya diganti dengan kewenangan Mahkamah Konstitusi, sehingga putusan Mahkamah Konstitusi tidak dilematis menjadi final dan tidak bisa dianulir oleh lembaga manapun. (2) sebaiknya dalam perekrutan hakim Mahkamah Konstitusi dilakukan oleh Komisi independen melalui rekruitemen seleksi alamiah, tidak boleh diajukan oleh Presiden 3 orang, DPR 3 Orang dan Mahkamah Agung 3 orang. Dengan demikian, putusan yang diambil dalam hal pelanggaran yang dilakukan oleh Presiden dan/atau Wakil Presiden benar-benar independent, netral dan berwibawa.

\section{UCAPAN TERIMA KASIH}

Berisi ucapan terima kasih kepada pihak kampus yang telah memberikan bantuan selama pelaksanaan penelitian/penulisan artikel. 


\section{DAFTAR PUSTAKA}

Abdul Latif, " Pilpres dalam Perspektiiif Koalisi Multipartai ", dalam Jurnal Konstitusi Volume 6, Nomor 3, Setjen dan Kepaniteraan MK, Jakarta, 2009.

Abdul Latif, Fungsi Mahkamah Konstitusi (Upaya Mewujudkan Negara Hukum Demokrasi), Jakarta: Kreasi Total Media, 2009.

Ahmad Fadlil Sumadi, "Hukum Acara MK dalam Teori dan Praktek “, dalam Jurnal Konstitusi, Volume 8 Nomor 6, Jakarta, 2011.

Ahmad Fadlil Sumadi, Hukum Acara MK dalam Teori dan Praktek “, dalam Jurnal Konstitusi, Volume 8 Nomor 6, Jakarta, 2011.

Arend Lijphart, Sistem Pemerintahan Parlementer dan Presidensial, Jakarta: PT.Raja Grafindo Persada, 1994.

Feri Amsari, "Masa Depan MK Kesesuaian Teori dan Implementasi ", dalam Jurnal Konstitusi Vol 5, Jakarta, 2008.

Hamdan Zoelva, Pemakzulan Presiden di Indonesia, Jakarta: Sinar Grafika, 2011.

Jimly Asshiddiqie, Hukum Tata Negara dan Pilar-Pilar Demokrasi, Jakarta: Konstitusi Press, 2005.

Jimly Asshiddiqie, Mekanisme Impeachment dan Hukum Acara Mahkama Konstitusi" Kerjasama Mahkamah Konstitusi Republik Indonesia dengan Konrad Adenauer Stiftung, Laporan Penelitian, Jakarta, 2005.

Jimly Asshiddiqie, Sengketa Kewenangan Konstitusional Lembaga Negara, Jakarta: Konstitusi Press, 2006.

Kitab Undang-Undang Nomor 8 Tahun 1981 Tentang Kitab Undang-Undang Hukum Acara Pidana

Laica Marzuki, Berjalan-Jalan di Ranah Hukum, Cet. 1, Jakarta : Konstitusi Press, 2005.

Laica Marzuki, Dari Timur ke Barat Memandu Hukum, Jakarta: Setjen dan Kepaniteraan Mahkamah Konstitusi, 2008.

Mahfud M.D., Perdebatan Hukum Tata Negara, Jakarta: Rajawali Pers, 2011.

Malik, " Telaah Makna Hukum Putusan MK yang Final dan Mengikat ", dalam Jurnal Konstitusi Volume 6, Nomor 1, 2006.

Maruarar Siahaan, Hukum Acara mahkamah Konstitusi Republik Indonesia, Jakarta: Sinar Garafika, 2011

Muhammad Bahrul Ulum,“ Mekanisme Pemakzulan Presiden dan/atau Wakil Presiden Menurut UUD 1945 (Antara Realitas Politik dan Penegakan Konstitusi) “, dalam Jurnal Konstitusi, Setretariat Jenderal dan Kepaniteraan MKRI, Volume 7, Nomor 4, Jakarta, 2010.

Ni'matul Huda, Hukum Tata Negara Indonesia, Jakarta: PT. Raja Grafindo Persada, 2007.

Ni'matul Huda, UUD 1945 dan Gagasan Amandemen Ulang, Jakarta: Rajawali Press, 2008.

Patrialis Akbar, Lembaga-Lembaga Negara menurut UUD NRI 1945, Jakarta: Sinar Grafika, 2013.

Peter Mahmud Marzuki, Penelitian Hukum, Ed. I, Cet. VII, Jakarta: Kencana Prenada Media Group, 2011.

Soewoto Mulyosudarmo, Pembaharuan Ketatanegaraan Melalui Perubahan Konstitusi, Malang: Asosiasi Pengajar HTN dan HAN Jawa Timur dan InTrans, 2004. 
Soimin dan Mashuriyanto, Mahkamah Konstitusi dalam Sistem Ketatanegaraan Indonesia, Yogyakarta: UII Press, 2013.

Soimin, Impeacment Presiden \& Wakil Presiden di Indonesia, Yogyakarta: UII Press, 2009.

Van Apeldoorn, Pengantar Ilmu Hukum, Cet. 24, (terjemahan Oetarid Sadino), Jakarta: PT Pradnya Paramita. Terjemahan dari Inleiding Tot de Studie van het Nederlandse Recht, 1990.

Wirjono Prodjodikoro, Tindak-Tindak Pidana Tertentu di Indonesia, Ed. III, Bandung: Refika Aditama, 2003. 